\title{
In Search Of An Integrative Theme For The Undergraduate Business Curriculum
}

\author{
W. Richard Sherman, (E-mail: rsherman@sju.edu), Saint Joseph’s University
}

\begin{abstract}
The Business Core is typically a set of courses in the curriculum of many business schools which provides the student with a breadth of knowledge across all business disciplines. The purpose of this paper is to introduce a curricular model based upon the balanced scorecard (BSC) developed by Kaplan \& Norton (1996). With its multi-dimensional approach that encompasses all business disciplines, the BSC framework provides a natural vehicle for integration. Moreover, with the flexibility in the choice of Key Performance Indicators (KPIs) and the potential for adding other perspectives, the BSC is infinitely adaptable and expandable.
\end{abstract}

\section{INTRODUCTION}

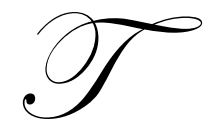

he Business Core is typically a set of courses in the curriculum of many business schools which provides the student with a breadth of knowledge across all business disciplines. This business core achieves the desired objective of breadth of coverage; however, it does so often at the expense of creating a relatively inflexible curriculum. Moreover, as commonly delivered at most universities and colleges, the collection of separate courses promotes the continuing isolation of business disciplines and the accompanying rigid thought processes that focus on an individual functional discipline as the preferred solution for many of today's issues. While this approach of seeing a particular situation as an accounting problem or a marketing problem or a human resource issue may have worked in the past, the creation and maintenance of functional silos is simply no longer viable since it limits the ability of organizations, their managers and their employees to confront today's problems and reach optimal solutions. A more balanced and integrative approach is needed. The balanced scorecard (BSC) developed by Kaplan \& Norton (1996) provides just such an integrative approach.

In a non-curricular setting, the BSC is designed to align corporate goals and performance rewards, utilizing both financial and non-financial measures. By its very nature, it cuts across disciplines, turning functional silos on their sides. The BSC approach allows finance and accounting to interface with marketing and production; it not only facilitates but requires operations to work with organizational design. In short, the BSC provides a comprehensive approach for considering the full impact of some decisions while at the same time helping to solve smaller isolated problems that can more readily be seen within its structure. It strikes "the balance between short- and long-term objectives, between financial and non-financial measures, between lagging and leading indicators, and between external and internal performance perspectives" (Kaplan \& Norton, 1996, p. viii). In a curricular setting, the BSC provides a flexible, integrative, and unifying theme upon which the business core can be built. This is not to say that using the BSC in practice or as a curricular model is easy. With its multi-dimensional approach that encompasses all business disciplines, the BSC requires both conceptual underpinnings and careful application to reach its full potential. 


\section{THE BALANCED SCORECARD AND ITS FOUR PERSPECTIVES}

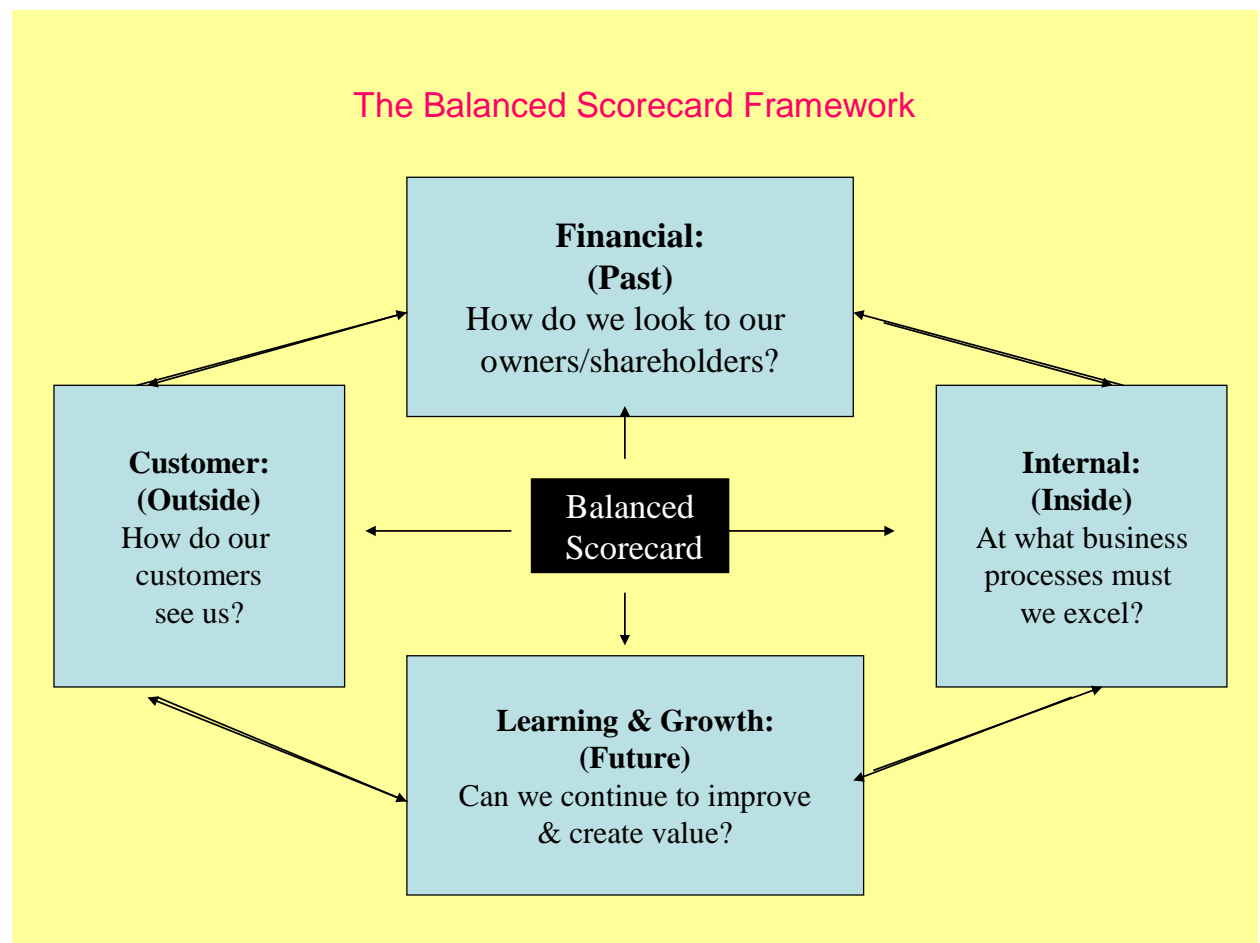

(Adapted from Kaplan \& Norton, 1992, p. 72)

As the above diagram illustrates, the BSC explicitly addresses four value drivers of organizational performance - financial, customer, internal, and learning \& growth. Another way of expressing the BSC is it views an organization through four different but inter-related lenses - in terms of past performance, future potential, an outsider's view, and an insider's perspective. Traditionally, decision-makers have focused primarily, if not exclusively, on financial measures such as profitability, cash flow, sales growth and return on equity to assess a company's performance. However, such a focus fails to capture the necessary interrelationships among the perspectives. In addition, the use of financial measures alone does not and can not capture the value created by intangible assets (measures in the growth \& learning perspective) which often create the competitive advantage for a company (Kaplan \& Norton, 2001; Lev, 2001). Furthermore, disappointing financial results often stem from serious problems in core business processes (i.e., measures in the internal perspective). Most critically, as one author notes, using financial measures alone is like driving a car looking through the rear view mirror (Niven, 2005).

The BSC approach looks to measures that drive value creation and how the measures in each perspective interrelate. The customer perspective "defines the value proposition the organization intends to use to generate sales and loyalty from targeted customers" (Kaplan \& Norton, 2004a, p. 54). Popular types of customer-related measures such as customer satisfaction and customer retention gauge how well a company serves its customers and obtains new ones. However, in order to deliver on its value proposition, the company must develop sound organizational procedures, efficient production systems and on-time delivery schedules. These are types of internal business processes which need to be understood by employees in order to provide high quality goods and services. Finally, an infrastructure of information systems and employee work groups support production and service. Kaplan and Norton (2004a) group these aspects of human capital (skills, training, knowledge), information capital (systems, databases, networks), and organization capital (culture, leadership, alignment, teamwork) into the "future" component of the BSC. Consequently, research and development activities as well as employee productivity, employee satisfaction and employee retention are some indicators of the learning and growth component. 
These four perspectives are not all-inclusive. Differing strategies of organizations dictate what should be included in the scorecard. This is the beauty of the BSC. It can be adapted and expanded to include metrics on leadership (Van De Vliet, 1997), supplier relationships (Partridge \& Perren, 1997), workforce diversity (Knouse \& Stewart, 2003), the strategic readiness of intangible assets (Kaplan \& Norton, 2004a), community investment (Kaplan \& Norton, 2004b), and/or corporate social responsibility (Crawford \& Scaletta, 2005). Indeed, Kaplan \& Norton (1996) suggest any stakeholder interest which defines a business unit's mission should be included in the BSC.

It is important to recognize the hierarchical nature of the BSC. Kaplan \& Norton's basic model assumes that financial performance is the ultimate goal of a business (Bryant, Jones \& Widener, 2004).

\section{The Balanced Scorecard}

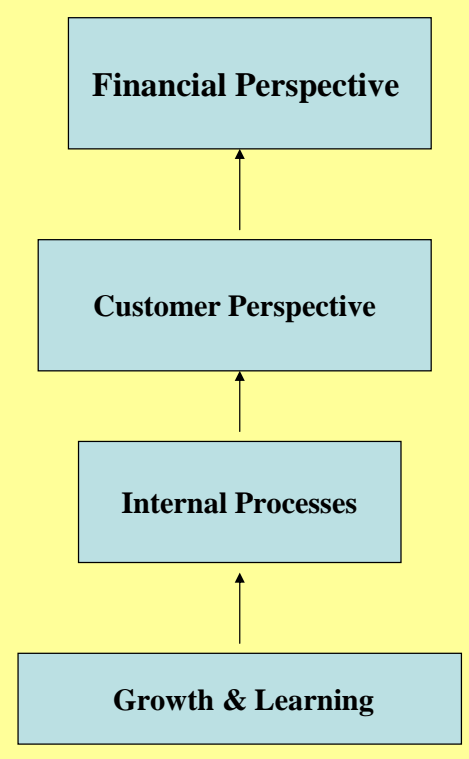

As the above diagram depicts, lead indicators in the Growth \& Learning, Internal, and Customer Perspectives drive future financial performance. In effect, financial measures merely report the outcomes from past actions in the lower levels in the hierarchy. The key to the successful implementation of the BSC is to find the cause-and-effect linkages that create value (Kaplan \& Norton, 2001). For example, investment in employee training (Learning \& Growth Perspective) will have an impact on innovation, customer management, quality enhancement and other business processes (Internal Perspective), which, in turn, will create greater customer satisfaction (Customer Perspective), resulting in superior financial outcomes (Financial Perspective).

Van der Woerd \& van den Brink (2004) offer a modification of the traditional BSC. Set within the European Corporate Sustainability Framework (ECSF), the "Responsive Business Scorecard" (RBS) adds a fifth perspective to the traditional BSC. 


\section{The Responsive Business Scorecard}

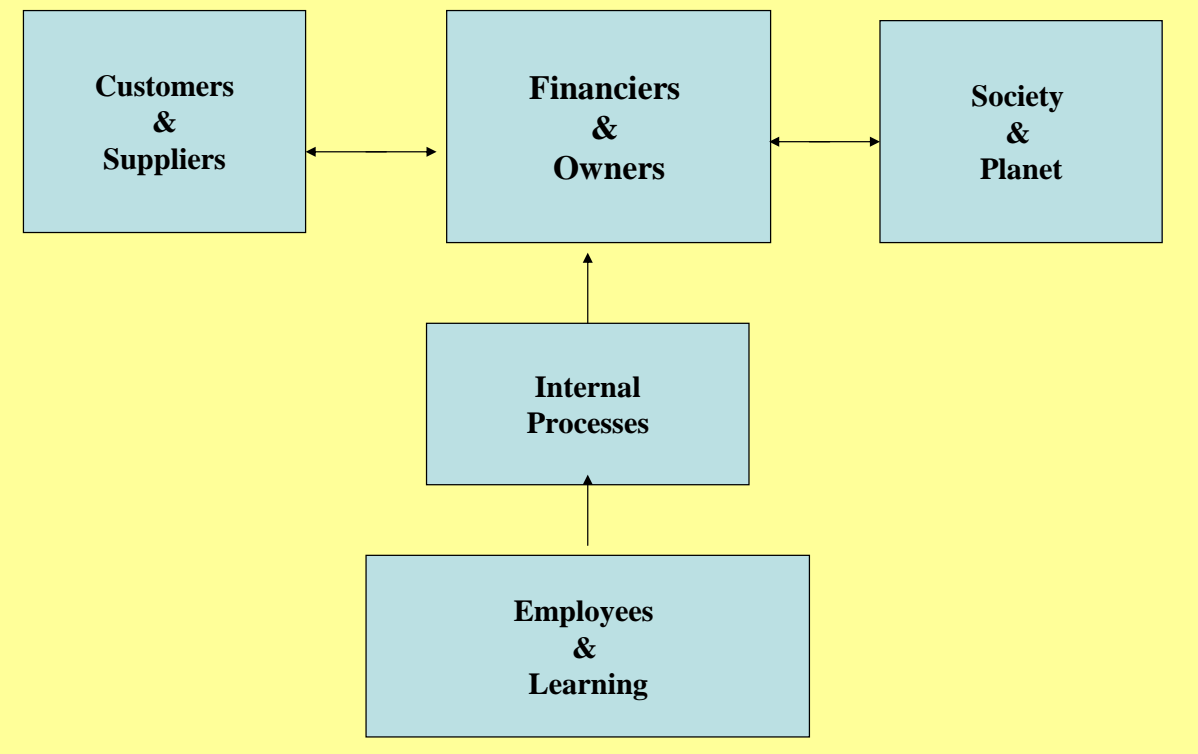

(Source: van der Woerd \& van den Brink, 2004, p. 178).

This model would be particularly useful in discussions about sustainable business practices inasmuch as it explicitly adds Society \& Planet to the stakeholders whose interests the organization must satisfy. Unlike the traditional BSC which emphasizes profit as the ultimate goal, "in a RBS, People and Planet must become on equal footing with Profit" (van der Woerd \& van den Brink, 2004, p. 177). While this may seem like a pie-in-the-sky concept, it is remarkably similar to the BSC already used by the Danish healthcare company Novo Nordisk with its four perspectives - Finance, Customer \& Society, Business Processes, and People \& Organization (INSEAD, 2003).

\section{A CASE IN POINT: THE BUSINESS CORE AT SAINT JOSEPH'S}

In addition to twenty liberal arts courses which comprise the General Education Requirement (GER) for all students at Saint Joseph's University, students in the Haub School of Business (the HSB) must complete a common Business Foundation. The required Business Foundation includes two specified GER courses in Economics (Micro and Macro) together with ten business courses:

ACC 1011: $\quad$ Financial Accounting

ACC 1021: $\quad$ Managerial Accounting

MGT 1001: $\quad$ Legal Environment of Business

DSS 1311: $\quad$ Business Statistics

FIN 1341: $\quad$ Introduction to Finance

MGT 1011: $\quad$ Organizations in Perspective

MKT 1011: $\quad$ Principles of Marketing

DSS 1011: Introduction to Information Systems

DSS 2011: Quantitative Methods for Business

BUS 2901: Business Policy 
When compared to the other 25 Jesuit schools of business, ${ }^{1}$ the HSB's Business Foundation requirements fall in the middle of the range of number of courses required in these schools' Business Core. ${ }^{2}$ To a very large degree, this required core of courses is dictated by the accreditation standards set by the Association to Advance Collegiate Schools of Business International (AACSB). ${ }^{3}$

However, the AACSB makes clear:

Topical Coverage Must Fit the School's Mission

There is no implication in these standards that these topics designate particular courses or treatments. Schools should assume great flexibility in fashioning curricula to meet their missions and to fit with the specific circumstances of particular programs. Some of these topics may be emphasized for particular learning needs and others may be de-emphasized. Combinations of topics may be grouped to integrate learning (AACSB, 2006, p. 69).

The HSB does attempt to align its curriculum with the University's Jesuit mission while at the same time achieving the topical coverage of the AACSB curriculum standards. However, it does so in a relatively nonintegrative way. The one exception to this lack of integration is in the capstone course - Business Policy. This 4credit course (all the other courses in the Business Foundation are 3-credit courses) is team-taught by a crossdisciplinary/department faculty. For more on this course, see Porth \& Sherman (2006).

\section{AN INTEGRATED BUSINESS CORE}

In looking at the AACSB Curriculum Standards in general, and at Saint Joseph's Business Core in particular, it is evident that to a very large degree the current curriculum and the BSC cover the same ground. However, by explicitly framing business issues in terms of four interrelated perspectives - financial, customer, internal business, and learning \& growth - the BSC achieves a level of integration among participating business functions that is not found in the conventional business curriculum. One of the unique features of the proposed integrated Business Core using the BSC is its attention to functional integration and flexibility. While it might at first appear that the financial perspective would involve only finance or accounting course offerings, the BSC framework quickly makes apparent that it has lasting effects on other areas of the curriculum. Consequently, management and human resource faculty should have a lot to say in the financial perspective. This same logic applies to the customer focus where marketing courses would be expected to dominate but where accounting and others offerings provide an important array of skills ranging from activity-based costing numbers to human resource management and information systems impact corporate strategy and goals.

In structuring the proposed curriculum, newly designed courses in "Information Literacy" and an "Introduction to Business - A Balanced Scorecard Approach" should be introduced in the freshman year. It is imperative that students be given this starting point at the beginning of their college careers in order to provide a broader, yet focused, framework for the remainder of the Business Core. These courses set the tone of an integrative business curriculum that moves away from individual business disciplines considered in isolation to placing decision-making at the center of undergraduate education.

Team-taught courses are more expensive than those taught by individual faculty. Nonetheless, "Introduction to Business" should be cross-functional, cross-disciplinary course, utilizing members from each department in the business school. Not only does this better facilitate the necessary coordination among faculty teaching the course and integration of topical coverage, it assures that each discipline gets its due and provides each

\footnotetext{
${ }^{1}$ Given the unique mission of Jesuit Colleges \& Universities, it is most appropriate to compare the curriculum of Saint Joseph's University with those of other Jesuit schools. Of the twenty-eight Jesuits universities and colleges in the United States, two - the College of the Holy Cross and University of Detroit-Mercy - do not have undergraduate business programs.

${ }^{2}$ Creighton has the fewest number at 8; University of San Francisco is the highest in requiring 17 courses.

${ }^{3}$ Five of the Jesuit schools of business - Le Moyne, Regis, Saint Peter's, Spring Hill, and Wheeling Jesuit - are not AACSBaccredited and, consequently, are not formally subject to the AACSB curriculum standards. However, inasmuch as AACSB standards constitute "best practices", these schools also have a similar Business Core in their curriculum.
} 
department an opportunity to "sell" its major to the freshman class. Given that faculty have themselves fallen victim to the functional silo effect, schools need to be cognizant of the required departmental support for the faculty and course development. For example, marketing faculty may need some additional training to get up to speed on how activity-based costing can be applied to their field; accounting faculty may need to re-tool on the strategic implications of various alternatives. More complex case materials will be needed for use in this and later courses.

While the BSC is the primary vehicle developed here to integrate a Business Core, there are other features to enhance both the delivery and content of undergraduate business education. The newly developed information literacy course would utilize the ERP systems that will be used throughout the business curriculum. The data design and application portions of this course foster the decision content necessary in a variety of decision areas. This central data base approach helps create new linkages not normally apparent from individual discipline study. It allows students the opportunity to see a far bigger and brighter picture than is normally seen from a one-dimensional system.

The BSC courses that replace the Principles of Marketing, Financial Principles, Management, and Legal Environment of Business offerings in a traditional Business Core must involve more than just changing the course title. (See Appendix A for tentative BSC Core course descriptions.) The approach must be integrative and focus on value creation - for the organization and for the student. Ideally, the courses would be team-taught. However, the specific application of course content utilizing the BSC approach may vary from integrated cross-disciplinary projects within courses to cross-departmental team-teaching.

Since the BSC helps integrate strategy throughout the curriculum, the Business Policy capstone course no longer needs to act as a stand-alone strategic management course. The emphasis of the Policy \& Business Analysis capstone course can shift to crafting a corporate strategy. The use of business analysis, with its emphasis on financial analysis, helps integrate materials from other courses - accounting, finance, marketing, and economics. Thus, students are better able to appreciate the interrelationships of all these disciplines in arriving at equity valuations or credit evaluations just to name a few of the decision areas covered in the course. Overall, the BSC allows problems to be expanded to a greater level of realism and the proposed solutions to be closer to those found in the real world.

Any school of business would and should develop its own scorecard to follow the AACSB admonition that "topical coverage must fit the school's mission" (AACSB, 2006). The BSC model is almost infinitely expandable and can be modified to meet the particular mission, objectives, and strengths of the school or program. For example, Jesuit schools of business would probably want to include dimensions for social justice, social responsibility, and ethical decision-making in their BSC Business Core. [For more on the mission of Jesuit colleges and universities in the U.S., see the Superior General of the Society of Jesus, Fr. Peter-Hans Kolvenbach's speech at the $32^{\text {nd }}$ General Congregation of Jesuit Colleges and Universities (Kovlenbach, 2000).] These themes would start with the Introduction to Business course in the freshman year but would continue to be woven throughout the business curriculum. For example, the Financial Perspective courses (BSC 201-202) would move beyond the traditional coverage of accounting courses with introduction of "Triple Bottom Line" (economic, environmental, and social bottom lines, also known as "Triple P" = People, Profits, and Planet) reporting techniques that help students appreciate that there are additional measures of organization performance beyond mere financial results. Building on this understanding, the impact of Triple Bottom Line reporting on traditional capital budgeting and other analytical techniques would be discussed in BSC 301.

Along similar lines, BSC 204 would not be just another Legal Environment of Business (LEB) or Business Ethics course. Instead, issues of sustainability and social justice are highlighted and emphasized with the introduction of the Responsive Business Scorecard (van der Woerd \& van den Brink, 2004). 
A diagram of how this new Jesuit Business Core would look is as follows:

\section{The Business Core in a BSC Framework}

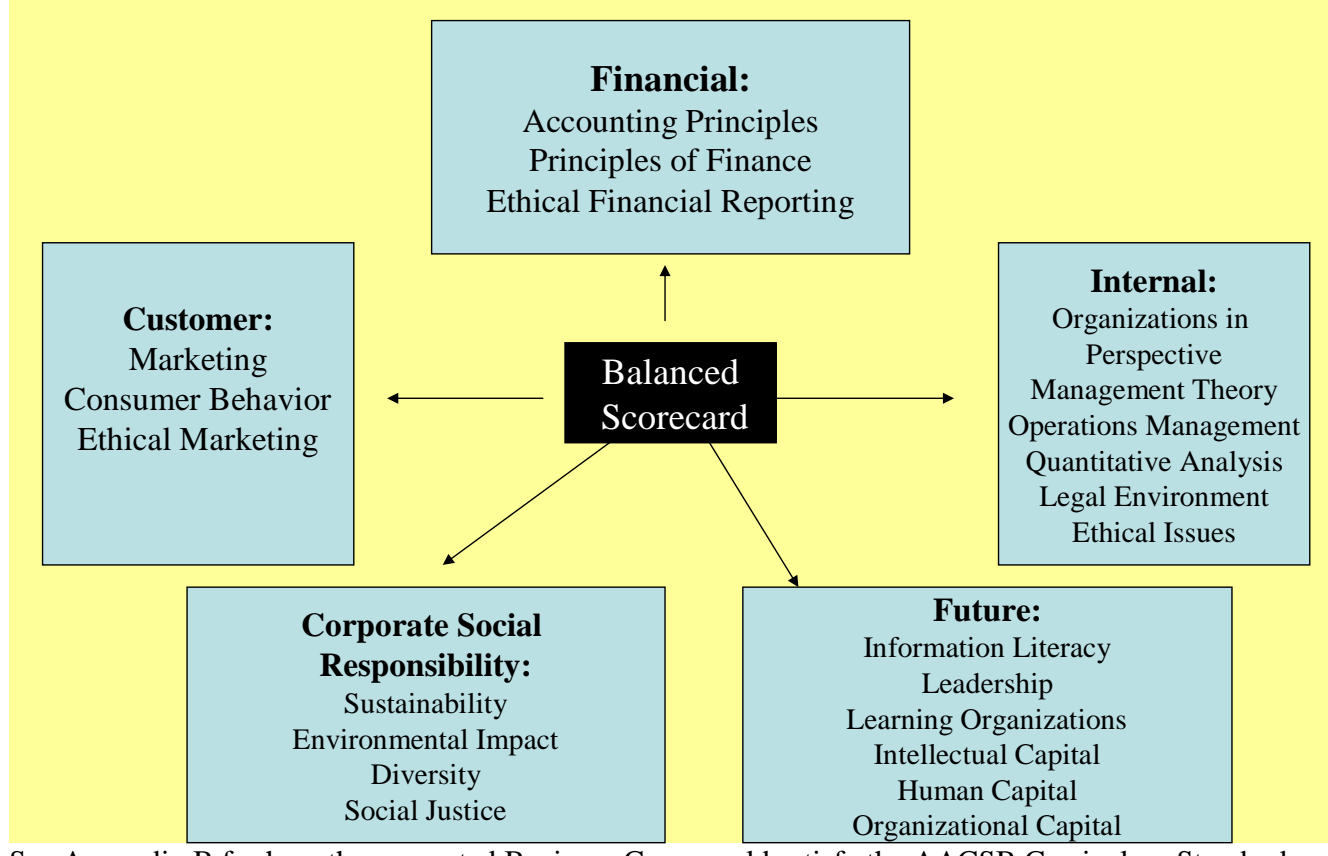

See Appendix B for how the suggested Business Core would satisfy the AACSB Curriculum Standards.

\section{CONCLUSION}

"Changing the curriculum . . . is harder than mowing a graveyard."

Thelin (2000, p. 9)

As faculty, we are constantly in search of better ways to facilitate our students' learning. We experiment with different pedagogical methods, change course coverage and emphasis, attempt to integrate technology and other resources into the subjects we teach. Periodically, we revisit our assumptions and review our entire curriculum. If there is a common failing in our design of a Business Core, it is the reinforcement of the functional silos by specifying a list of particular courses, housed in particular business departments, taught by faculty trained in a particular discipline. Students are presented with disconnected pockets of information, tools, skills, and perspectives. The connections and interrelated-ness of the business world is lost. In effect, most Business Cores assume what Kaplan \& Norton (2001) characterize as a balance sheet model. "The balance sheet is a linear, additive model. It records each class of assets separately and calculates the total by adding up each asset's recorded value" (at p. 88). In the typical Business Core, the value of the curriculum is the sum of the values of the individual courses which comprise that curriculum. However, "the value-creation process is multiplicative, not additive" (Kaplan \& Norton, 2001 , p. 89). Value-creation depends on the context of the assets' use - the organization, the strategy, and other complementary assets. Similarly, the value created by a curriculum is multiplicative. It is the context in which the concepts, issues, tools, and analyses are presented that creates value. 
With its multi-dimensional approach that encompasses all business disciplines, the BSC framework provides a natural vehicle for integration, for establishing the context of the courses in the Business Core. Moreover, with the flexibility in the choice of perspectives and the metrics used within each perspective, the BSC is infinitely adaptable and expandable. Of particular interest to Jesuit schools of business in the design of their BSCbased Business Core would be the inclusion of strong underpinnings in business ethics, social responsibility, and sustainability. By selecting particular Key Performance Indicators (KPIs) or even adding other perspectives to the traditional BSC model, Jesuit schools of business would not only assure that the topical coverage of their Business Core would "fit the School's Mission", they would provide a context in which social justice is more than just an abstraction. Social justice would become a lead indicator of future organizational success.

\section{REFERENCES}

1. $\quad$ AACSB (2006). Eligibility Procedures and Accreditation Standards for Business Accredition. http://www.aacsb.edu

2. Bryant, L., D.A. Jones \& S.K. Widener (2004). Managing value creation within the firm: An examination of multiple performance measures. Journal of Management Accounting Research. 16:106-131.

3. Crawford, D. \& T. Scaletta (2005). The balanced scorecard and corporate social responsibility: Aligning values for profit. CMA Management (October 2005): 20-27.

4. INSEAD (2003). Presentations of the Balanced Scorecard and Sustainability Conference. Fontainbleu, France. November 20, 2003.

5. Kaplan, R.S. \& D.P. Norton (1992). The balanced scorecard: measures that drive performance. Harvard Business Review (Jan-Feb 1992): 71-79.

6. Kaplan, R.S. \& D.P. Norton (1996). The balanced scorecard: translating strategy into action. Boston, Mass.: Harvard Business School Press.

7. Kaplan, R.S. \& D.P. Norton (2001). The strategy-focused organization: How balanced scorecard companies thrive in the new business environment. Boston, Mass.: Harvard Business School Press.

8. Kaplan, R.S. \& D.P. Norton (2001). Transforming the balanced scorecard from performance measurement to strategic management: Part 1. Accounting Horizons 15(1): 87-104.

9. Kaplan, R.S. \& D.P. Norton (2004a). Measuring the strategic readiness of intangible assets. Harvard Business Review (Feb 2004): 52-63.

10. Kaplan, R.S. \& D.P. Norton (2004b). Keeping score on community investment. Leader to Leader (Summer 2004) 33: 13-19.

11. Knouse, S. B. \& J.B. Stewart (2003). "Hard" measures that support the business case for diversity: A balanced scorecard approach. Overcoming Barriers to Opportunity 11(4): 5-10.

12. Kovlenbach, Peter-Hans (2000). The service of faith and the promotion of justice in American Jesuit higher education. $32^{\text {nd }}$ General Congregation of Jesuit Colleges \& Universities. Santa Clara,CA.

13. Lev, B. (2001). Intangibles: Management, Measurement, and Reporting. Washington DC: Brookings Institution Press.

14. McKenzie, F.C. \& M.D. Shilling (1998). Avoiding performance measurement traps: Ensuring effective incentive design and implementation. Compensation \& Benefits Review 30 (4): 57-65.

15. Niven, P.R. (2005). Driving focus and alignment with the balanced scorecard. The Journal for Quality \& Participation (Winter 2005): 21-43.

16. Olve, N.G., J. Roy \& M. Wetter (1999). Performance drivers. Chichester: John Wiley and Sons Ltd.

17. Partridge, M. \& L. Perren (1997). Winning ways with a balanced scorecard. Accountancy 120: 50-51.

18. Porth, S. \& W.R. Sherman (2006). Business policy with an Ignatian twist. Presented at the $9^{\text {th }}$ Annual Conference of the Colleagues in Jesuit Business Education. Spokane, WA. July 28-30, 2006.

19. Thelin, J. (2000). A legacy of lethargy? Curricular change in historical perspective. Peer Review, 2(4).

20. Van de Vliet, A. (1997). A new balancing act. Management Today: 78-80.

21. Van der Woerd, Frans \& Timo van den Brink (2004). Feasibility of a responsive business scorecard - a pilot study. Journal of Business Ethics 55: 173-186. 


\title{
APPENDIX A: THE BSC MODEL FOR THE BUSINESS CORE
}

\author{
GER Courses Specific to Business Majors: Macro \& Macro Economics \\ BSC 101: Introduction To Business - A Balanced Scorecard Approach
}

An introduction to organizational forms, goals and strategies as well as the relationship of business disciplines within the organization are covered in this course. The balanced scorecard is introduced as a management tool and integrative framework for further study. Integrated presentations from business departments covering each functional business area highlight the course.

\section{BSC 102: Information Literacy}

Using a Management Information Scorecard (MIS) framework and including an introduction to Enterprise Resource Planning (ERP) software, this course will examine the design and structure of information systems and their importance of in providing the data for decision-making. The topical coverage will emphasize the role that technology plays in management efforts to achieve competitive advantage in an information age.

\section{BSC 201-202: The Financial Perspective I \& II: Financial Analysis For Decision-Making: Uses \& Users}

The first accounting course emphasizes financial statements and their use to external decision makers. The role of generally accepted accounting principles and their limitations are covered. An introduction of "Triple Bottom Line" (Triple P) reporting techniques will help student appreciate that there can be additional measures of organization performance beyond mere financial results. Tools and techniques of financial analysis are explored through a project integrating internet research, business strategy/industry analysis, accounting rules and financial ratio analysis.

Managerial accounting focuses on the role of accounting to managers and internal users. Coverage includes cost behavior patterns/classifications and the problem solving functions of accounting as they pertain to planning, control, performance evaluation, and special decisions. Strategic cost analysis is introduced through techniques such as activity based costing to improve decision making. Case analysis is used to integrate ERP and the balanced scorecard. Techniques developed by the Environmental Protection Agency (EPA) and others for monetizing environmental impacts and their effects on decision-making are also covered.

\section{BSC 203: The Internal Perspective I: Organizations In Perspective}

A comprehensive introduction to the theory and practice of management. Functions of planning, organizing, leading, and controlling provide a central theme for discussing the interrelationships among organizational theory, individual behavior, interpersonal relations, and effective management practices in a global economy. A balanced scorecard case is utilized integrating the multi-dimensional issues faced by management including the importance of both financial and non financial measures and the overlapping issues in scorecard design. Stakeholder theory and issues of social responsibility are woven throughout the topical discussions.

\section{BSC 204: The Internal Perspective II: Production \& Operations}

This course introduces the concepts and techniques of designing and managing manufacturing and service systems and their operations. Major topics include product and process design, facility location, forecasting, materials management, quality assurance, productivity, and global competitiveness. Measurement issues and internal process components of the balance scorecard are captured in case analysis. 


\section{BSC 205: The Internal Perspective III: The Socially Responsible Business}

The strategies by which organizations in the private as well as public sectors interact with, adapt to, and attempt to influence their external environments are explored. The primary focus is on evaluating the effect of business and governmental decisions on the quality of life. The role of regulatory agencies and the impact of legislation on organizational behavior are considered. Issues of sustainability and social justice are highlighted and emphasized throughout this course with the introduction of the Responsive Business Scorecard (van der Woerd \& van den Brink, 2004).

\section{BSC 206: The Customer Perspective: Marketing Concepts \& Applications}

Market characteristics, consumer buying habits, marketing functions, and the fields of retailing are examined. Concepts and current practices in product development, pricing, promotion, distribution and international marketing are studied. The integration of strategic costing and activity based accounting as well as an emphasis on the customer focus of the balanced scorecard are highlighted through case analysis.

\section{BSC 301: The Financial Perspective III: Financial Management}

An introduction to the environment, concepts, and techniques of financial management. Topics include organizational form, financial planning and analysis, financial markets, interest rates, bond and stock valuations, risk and return, capital budgeting, cost of capital, and international finance. The development of the financial dimension for a balanced scorecard and the study of economic value added (EVA) helps integrate many of those issues. The impact of Triple Bottom Line reporting on traditional capital budgeting and other analytical techniques will be discussed.

\section{BSC 302: The Future Perspective: Intellectual Capital}

A consideration of the factors which enable an organization to not only survive, but to learn and thrive. Topics will include but are not limited to employee competence and growth, human resource management, innovation, leadership, human and organizational capital. Particular attention to how BSC metrics can promote the development of intellectual capital (i.e., intangibles).

\section{BSC 401: Policy \& Business Analysis}

This is a capstone course integrating the various business functions in the development and implementation of business strategy. It examines cases involving policy formulation and decision-making in the present-day business environment. Using an integrative balanced scorecard approach across the business disciplines, this course uses an inter-disciplinary cased-based format, using a strategic management framework including faculty from business departments.

\section{APPENDIX B: AACSB CURRICULUM CONTENT (Standard 15) \& HOW IT IS FULFILLED BY BSC BUSINESS CORE}

- Global, environmental, economic, legal, and regulatory context for business. (BSC 101; BSC 203; BSC 205; BSC 401)

- Individual ethical behavior and community responsibilities in organizations and society. (BSC 101; BSC 205; BSC 401)

- Management responsiveness to ethnic, cultural, and gender diversity. (BSC 101; BUS 203; BSC 205; BSC 401)

- $\quad$ Statistical data analysis and management science as they support decision-making processes throughout an organization. (BSC 204; BSC 401) 
- Information acquisition, management, and reporting (including information management and decision support systems for accounting, production, distribution, and human resources). (BSC 101; BSC 102; BSC 201-202; BSC 204; BSC 401)

- $\quad$ Creation of value through integrated production and distribution of goods, services, and information (from acquisition of materials through production to distribution of products, services, and information). (BSC 101; BSC 202; BSC 204; BSC 206; BSC 401)

- $\quad$ Group and individual dynamics in organizations. (BSC 101; BSC 203; BSC 401)

- Human resource management and development. (BSC 101; BSC 203; BSC 302; BSC 401)

- $\quad$ Finance theories and methods; financial reporting, analysis, and markets. (BSC 101; BSC 201-2; BSC 301; GER ECN)

- $\quad$ Strategic management and decision-making in an integrative organizational environment. (BSC 101; BSC 401)

- $\quad$ Other management-specific knowledge and skills as identified by the school. (BSC 205; BSC 302)

\section{NOTES}


NOTES 